\title{
Jonson's Gossips and the Stuart Family Drama
}

1608-9 was a difficult year for James I of England as a monarch and as a father. His triumphal 1603 progress through England and the providentially thwarted threat of Gunpowder Plot in 1605 had lost their power to generate automatic goodwill for his domestic and foreign policies. The 1607 Parliament had been a disaster for James, refusing to pass his plan to create a 'Great Marriage' between Scotland and England. A major bone of contention was the question of whether or not Scottish children born before 1603 would become naturalized citizens of the putative 'Great Britain'. James impatiently berated the Parliament for nitpicking: '[The Union] is no more unperfect, as it is now projected, than is a child that is born without a beard. It is already a perfect union in me, the Head.' ${ }^{\prime}$ The failure of the Great Marriage was particularly galling to a monarch who was fond of envisioning his relationship with his nation as paternal. James returned frequently to the metaphor he introduced in his accession address to parliament, calling himself 'a loving nourish-father' who would provide the English people with 'their own nourish-milk' ${ }^{2}$ His own familial relations, however, were far from idealized. Intimate relations with his queen, Anna of Denmark, who had ended her childbearing years after enduring the deaths of two infant daughters in 1605 and 1607, had probably ceased; James's infatuation with Robert Carr dates from this period. Moreover, James was apparently growing increasingly resentful of the popularity of his charismatic son, Henry, and of his demands for an autonomous court of his own.

James's premier court poet, Ben Jonson, shared a fondness for paternal metaphors with his patron, and was contending with his own professional and family troubles in 1608-9 as well. His quest for patronage was considerably complicated by the triune nature of the royal court, and his chief rival for Queen Anna's patronage, Samuel Daniel, continued to enjoy greater favors than Jonson in spite of Jonson's more frequent writing commissions. Jonson's family life was apparently similarly unsettled, with compelling evidence that at least two illegitimate children were born in 1609. The 
parallels between the family life and career of both Jonson and his monarch have been noted for some time; indeed, an explicit linkage of family and professional issues characterizes the writing of both men. As James did for his 'father/king' metaphors, Jonson drew on classical sources for his frequent comparisons of poetic creation to paternity or even maternity, the most famous of which is his epigrammatic assertion that his first son should be thought of as 'Ben Jonson his best piece of poetry'.

Many critics agree, however, that Jonson's use of such metaphors reflected his own ambivalence about parenthood and authorship. ${ }^{3}$ It is therefore instructive to examine a literary product that Jonson addressed to all three members of the royal family in the context of the difficulties presented to both poet and monarch by the complex and often competing interests of the three-sided Jacobean court. That James's reliance on the 'nourish-father' metaphor was under considerable pressure is evidenced by complex metaphoric patterns in The Masque of Queens, which uses the Jonsonian innovation of the antimasque to contrast a vision of disruptive female sexuality (in the form of witches' coven secretly calling up a demon to attack the court) with a vision of the House of Fame, a symbol of female majesty and loyalty.

Familial metaphors reappear, in fact, in Jonson's next stage work. The fact that Jonson composed the sexual farce Epicoene immediately after Queens, Stephen Orgel notes, demonstrates a poetic tension between ideal and reality: between an idealized masculine judgment praised in his patrons (such as Lucy, Countess of Bedford and Elizabeth, Countess of Rutland) and a whorish or even 'tribade' rhetorical ambition in other women described in his epigrams, Epicoene, and Queens. ${ }^{4}$ David Riggs suggests that Jonson had by 1608 arranged his pattern of 'blaming and praising' into 'a richly dialectical relationship'. ${ }^{5} \mathrm{He}$ offers as an example the chronological relationship of Queens, Epicoene, and the pair of poems whose subject is Cecilia Bulstrode, one of Anna's gentlewomen of the bedchamber, whose own satiric doggerel and disdain for Jonson's work infuriated Jonson. His 'Epigram on the Court Pucell' is one of his most vicious pieces, attributing Bulstrode's witty productions to her 'epicoene fury' and sneering with obvious misogyny, 'with tribade lust she force[s her] Muse'. ${ }^{6}$ When she died in August 1609, Jonson was asked to write an epitaph for the woman he had savaged in verse. His praise for her modest virginity was, by his own admission, a mere literary conceit designed to show his own skill as a poet; privately, he worried that his open hostilities with Bulstrode had damaged his professional relationship with the ladies of Anna's court. ${ }^{7}$ 
While Riggs sees the relationship between Queens and Epicoene as dialectical, the praise of courtly women in the one balanced by the satire of female intellectual pretensions in the latter, such a reading glosses over both the power of the antimasque to subvert the masque's overt purpose, and the ameliorating power of farce in Epicoene. The tension, in other words, operates within, not between the two works. In Queens, neither the association of witches with female destructiveness nor the Amazon queens with feminine virtue is completely stable: the antimasque structure is ambiguous by design on topical, metaphoric, and metatheatrical levels, subverting any 'totalizing' message that may have been intended by its various makers. ${ }^{8}$ Likewise, readers of Epicoene have traditionally noted that the play offers no real source of moral satisfaction or communal festivity to offset the grotesque self-indulgence of the citizens or the silent misanthropy of Morose. ${ }^{9}$ Part of the symbolic complexity of the two works lies in their dependence on the ambivalent figure of the gossip as a source of social disruption.

The term gossip, when applied to a person, refers variously to female friends, attendants at the various rituals of childbirth, and groups of women who gather to denigrate men. Its etymological source is 'god-sib' - the close (female) relatives called in to witness (or at least attest to) a baptism. The term, however, had come by 1579 to refer to any loose-lipped woman 'of light and trifling character, esp., one who delights in idle talk'. ${ }^{10} \mathrm{~A}$ common feature of Queens and Epicoene is a comic 'chorus' of androgynous women who threaten traditional values while satirically functioning as gossips, attending and assisting a powerful female who more directly threatens the peace and stability of a male authority figure. In both works, the gossip is the metaphoric locus of disruptive speech, and shares identity borders with the various images of witch, midwife, and citizen wife, offering an additional lens through which to view the paternal metaphor Jonson employs on behalf of his royal patron.

Both groups of 'gossips' are ultimately silenced and subdued by an Amazonian figure who is nominally female, but who embodies male virtues consistent with the world of the text. However, in each case the Amazon is also conducted and enabled by a male figure who speaks for her (Heroic Virtue in Queens) or through her (Dauphine in Epicoene). In Queens, the allegorical character who silences the hags is 'Fama Bona,' or Good Fame, the daughter who speaks after being introduced by her symbolic father, Perseus in his function as Heroic Virtue. However, the House of Fame offers, both in its original incarnation in Chaucer's long poem and in Queens, at best an ambivalent expression of female virtue and autonomy; ${ }^{11}$ Good Fame, therefore, presents a similarly troubling figure for critics, who have disagreed 
whether she is devalued by her father's introduction and/or the masculine contexts of the masque, or whether she represents a genuine model of female regal power and reflects Queen Anna's intention to challenge the patriarchal discourse of the court masque with a feminized voice. ${ }^{12}$ She stands atop the House of Fame, a symbolic structure built by the honorable deeds and commemorative words of monarchs and poets. In Epicoene, the Collegiates and their ineffectual gallants are silenced not by Epicoene's words, but by the removal of 'his' wig, a removal which reveals Dauphine's witty plot. While some critics argue that the resourceful Epicoene - the improvising boy actor hired by Dauphine to play her - functions like the witty heroines of Shakespeare's cross-dressing comedies, ${ }^{13}$ he cannot continue as 'heroine'. Once the 'act' is over, Dauphine steps in to introduce the boy (who remains nameless), give his bona fides, and promise his future participation as a gallant. Epicoene is no mere puppet, but by the very fact of her actual masculinity, neither can $s /$ he be a figure of female wit in the mold of The Alchemist's Dol Common or The Devil is an Ass's Frances Fitzdotterel. ${ }^{14}$ Likewise, the witty heroes of Epicoene, with the protean boy-bride as their spokesperson, co-opt, imitate, and parody female speech in a way that does not clearly rectify the destructive nature of the comic villain Morose's misogyny and love of silence. ${ }^{15}$

In frustrating the alliance between the gossips and their androgynous leader, each work sets a form of feminized disruptive speech against a male-directed model of productive discourse. The seditious and chaotic babble of the hags in Queens finds a parallel in the socially disruptive chatter of the Collegiates. Queens suggests that the power of the patriarch-king to silence the illegitimacy represented by the hags requires at least a formal nod to the generative power of aristocratic women, even if that power is largely abstracted and robbed of a voice; Epicoene satirically problematizes James's 'nourish-father' metaphor by attacking Morose's fantasy of the nuclear family as a vehicle for controlling inheritance and also for controlling effeminate noise. ${ }^{16}$

Queens' antimasque structure, in which a scene depicting chaotic, subversive figures is superceded (and symbolically defeated) by a scene presenting triumphant, heroic figures, allows for the masque performance, perhaps more so than the printed text, to support 'acts of lobbying' between court and monarch, reflecting the shifting give-and-take of courtly power. ${ }^{17}$ In other words, the antimasque's burlesque was not merely a comic warm-up act for the courtly dancers. However, most of the scholarship regarding Queens elides the specific actions of the grotesque hags (which dominate nearly two-thirds of the performance) in favor of the political and gender-related ramifications 
of the classical figures on the House of Fame. ${ }^{18}$ The action of the antimasque presents an incomplete coven of eleven witches or hags who enter, dance 'with strange gestures' to 'a kind of hollow and infernal music', and then call on their leader, the Dame, to appear (1l. 30, 25-6). ${ }^{19}$ This figure, whose appearance reflects a pastiche of classical sorceresses including Canidia, Medusa, and Erictho, announces that their intent is to 'overthrow the glory of this night' (101), specifically, the masque occasion itself. To do so, they require the assistance of a demon, which they try to call up in a grotesque parody of a birthing ritual, burying a collection of disgusting ingredients (many associated with corpses) in the earth:

And when thou dost wake,

Dame Earth shall quake,

And the houses shake,

And her belly shall ache,

As her back were brake

Such a birth to make.

Later, they chant in a way that imitates the grunts of labour: "Hoo! Har! Har! Hoo!" (307). The stage becomes in effect a travestied birthing room; that the birth does not occur is indicative of the hags' impotence in the presence of the monarch, James, who claimed in Daemonologie that he alone had the power infallibly to detect, and thereby thwart, nation-threatening acts of witchcraft. ${ }^{20}$ But to enact labor, even parodically, is a daring dramatic project, calling up elements of the 'primal scene' that gave Jacobean tragedy its psychological fascination. ${ }^{21}$

'Let every foot be bare / And every knee', directs the Dame as the hags prepare to bring forth their demon-child (231-2). Jonson's text notes that the bare legs evoke the image of Medea in Ovid and Seneca (231n., p. 538); in performance, however, the subsequent chanting of the hags could not fail to evoke the image of labouring women as well, creating on stage, for an isolated moment, the ritual space of the birthing-chamber. Orgel stresses that masques 'were not, to the Renaissance, a form of drama,' but were allegorical rituals in which 'a deep truth about the monarchy was realized and embodied in action'.22 What might Jonson's staged evocation of the privy space of childbirth have meant to the monarch who witnessed it, keeping in mind that James unironically styled himself a 'cradle king'? As Alan Stewart has argued in his recent biography, the phrase takes on special resonance for historians who examine James's traumatic childhood experience with the maternal 
bond, which may have directly influenced his use of patriarchal metaphors in his kingship, as well as his attitudes toward maternal sexuality.

Tom Bishop suggests that the makers of masques found the ritual created in such events difficult to control, due to the unstable relationship between the 'suasive illusion of solemnity and tradition' associated with court ritual, and the subversive energies of the carnivalesque or grotesque called into being during the antimasque. ${ }^{23}$ Such a paradoxical relationship is present in the bodies of the staged hags and the 'body' of the masque text, both of which incorporate scholarly/classical and grotesque/folk elements. The hybrid nature of such cultural productions was particularly evident in any literature dealing with witchcraft, which tended to draw from contradictory sources in presenting witchcraft as a female as well as a state problem. ${ }^{24}$

Some of the folk-based details of the hags' ritual, such as midwifery and English herb lore, reveal in close reading resonances beyond those which Jonson offers in his marginalia. And the use of such material, particularly in the context of the parody of the birth rituals central to the antimasque, creates an atmosphere of distrust and disdain for 'women's magic', privileging the masculinized Amazons over the grotesquely female hags. However, many gender-critical studies focus on the Amazonian queens, and fail to consider what the witches are actually trying to $d o$; noting the chaotic nature of the witches and leaving it at that. ${ }^{25}$ The reasons that Jonson (and subsequently, his critics) tended to gloss over folkloric elements of the hags' rituals may be closely related to James's own intention in Daemonologie to demystify and denature the disruptive power of folk magic as practiced at the village level. Orgel argues that the witches, in evoking the 'conspiracy' James believed had been planned by the Berwick coven in 1590, reflect the Stuart 'family drama' and James's 'nourish-father' image. Therefore, the witches are represented as the opposites not only of Bona Fama and Bel-Anna, but also of Heroic Virtue, the legitimate father of Bona Fama, although he does not connect his thesis to the actions of the witches themselves. ${ }^{26}$

These actions challenge not only the serene majesty of James's court, but (symbolically) James' own totalizing metaphor of maternal/paternal generation. The imagery of the hags' monstrous birth functions as a foil not only to the 'getting' of Fame, of which Heroic Virtue boasts, but also directly to the monarch who prides himself on, at last, providing England with an unquestionably legitimate line of succession. Interpretations such as Orgel's argue that the challenge represented by the hags is effectively curtailed and contained by the appearance of the House of Fame. Such a message is certainly underscored by Jonson's marginalia: the sources for the hags' activities - 
classical, ecclesiastical, and popular - are bewilderingly multivalent, while for his annotations concerning the Amazonian Queens Jonson seems to have striven for elegant, succinct, and relatively dismissive summaries. ${ }^{27}$ Did the masque as theatrical artifact offer so complete a dismissal of the power of subversive female sexuality as the text seems to indicate? The continuation of the question explored in Epicoene and the temporary suppression of that play in the light of complaints by Arbella Stuart (which I will discuss later) implies that, for both Jonson and James at least, it did not.

The setting of Queens creates an intensely ironic metatheatrical moment: the hags have chosen an exposed piece of ground on which to parody the intimate, enclosed rituals of the lying-in chamber. ${ }^{28} \mathrm{~A}$ further irony inheres in the fact that the 'secret' outdoor location they have chosen is represented on an indoor stage under the penetrating gaze of the King and his court. The seclusion of the birthing room contrasts with a tradition (still in folk practice in the Jacobean era) that allowed a ritual invasion of the marital bed: the charivari, a term used to apply to both the public 'bedding' of the nuptial couple as well as the public display of the bridal bedsheets. In the court, the charivari maintained a purely metaphoric currency, but was the basis for a celebrated anecdote of James's typically tactless familial humor. On the morning after his daughter's wedding to Frederick, the Elector Palatinate, James visited the 'young turtles that were coupled on St. Valentine's day, and did strictly examine [the prince] whether he were his true son-in-law, and was sufficiently assured'. ${ }^{29}$ David Bergeron attributes this visit partly to James's often-inappropriate sense of bawdy humor, but also suggests James's sincere belief that no door was closed to the king, that even childbed secrets are as open to him as he claims witchcraft secrets to be.

Such an anecdote presents James in the role of the gossip, jokingly inquiring into the secrets of the marriage bed that, in the case of royal occupants, was important not necessarily as a site of personal pleasure, but as the place of conception and birth. ${ }^{30}$ As was customary in the case of his own wife and children, the initial privacy of the birthing room would have been brief, and afterwards, his rights of access were absolute. He allowed none of his children to be reared by Anna (and usually denied her the choice of foster parents as well), nor was she apparently present at this jesting allusion to charivari. In this context, however, James defines the ritual as a vehicle for legitimizing rather than questioning an important union; he stops short of displaying the stained wedding sheets, but only just. ${ }^{31}$ The presence of female blood, however coyly alluded to in royal anecdotes, is explicit in the hags' charms and contributes to the sexualized environment of the antimasque. 
Jonson's witches have filled a filthy ditch with little stuffed dolls, 'pictures full of wax and of wool' that have been pricked with pins but that lack a crucial ingredient: 'blood, to make up the flood' (79-82). The Dame's 'part' is to supply the blood; unlike the post-menopausal hags whose menstrual 'flood' has dried up, the Dame they call is still at least figuratively fertile, potent, possessing the power, signified by blood, to create a kind of life. Such 'fertility' is, as James asserts in Daemonologie, a grotesque illusion: whether Satan steals a dead body or merely its sperm in order to 'converse' with a woman, the sperm feels icy cold. Such cold seed cannot 'generate' and so all reports of monstrous demon-seeded births are by definition delusional. ${ }^{32}$

The sexual transgressions of the Queens hags are merely alluded to; their verbal crimes are explicit. Their allegorical names identify them with an escalating ladder of civil unrest and the attendant evils of uncontrolled talk: Ignorance, Suspicion, Credulity, Falsehood, Murmur, Malice, Impudence, Slander, Execration, Bitterness, and Rage all bring on Mischief (Ate, the Dame) in the same way their charms are designed to assist the demonic birth. Jonson's notes explain that he listed the 'vices' each hag represents in order, 'as if one link produced another, and the Dame was born out of them all', implying (with another birth-metaphor) that civil misrule derives directly from social misrule. Jonson's specific source is Claudian's description of the destructive goddess Alecto, who 'summons ... Night's children of ill-omened birth' (104n, pp. 530-1). In Queens, the 'discovery' of such crimes is both a legal project (in which James participated) and a theatrical one (for Jonson). Jonson associates the witches with gossips in order to reveal that the power they serve is ultimately not the generative power of the mother, but the impotent power of the Dame's envy. Willis likewise notes the connection: 'the witch had much in common with the shrew and the scold ... . [she] directed her angry words especially at other women.' 33 The monarch asked to view and judge the masque's grotesque parody of the birth ritual was, at the precise historical moment the masque was being performed, himself enmeshed in a web of envy and resentment relating directly to his function as a father and husband. The death of James and Anna's last daughter in 1607 seems to have poisoned an already rocky marriage, and that James, also depressed about the loss of the babies, was consoling himself with the affections of Robert Carr. ${ }^{34}$ This relationship did little to ameliorate James's increasing disagreements with Henry and Elizabeth, who had become full courtiers in their own right by 1608 , and whose popularity James openly resented (Roger Coke reported, regarding Henry's popularity: 'the King was heard to say, will he bury me alive?'). ${ }^{35}$ The very qualities associated in the 
minds of witch-finding authorities with the pathology of the female witch depression, envy, sexual otherness - ironically also plagued England's 'nourish-father'.

Into this emotional atmosphere Jonson projects an illegitimate lying-in 'chamber' not merely, as his annotations suggest, to provide a foil to the legitimacy of royal female virtue, but also to provide a foil to James's legitimate fatherhood, allowing him to claim his paternity figuratively unaided by Anna. The queens that occupy the House of Fame are defined in Jonson's notes as daughters and wives, not mothers, with the exception of Thomyris, whose emotions on the death in battle of her son are characterized as 'not the grief of so great a loss, in the juster comfort she took of a greater revenge' (449n, p. 543). 'Bel-Anna's' achievements, defined in the masque as 'worthiest,' are her humility, her beauty, and her 'truth of spirit,' all of which exist in deference 'to him that gave' them their 'worth' (398-406). Commissioned by Anna, the masque cannot, of course, problematize her maternity, but it can express patriarchal anxieties about the chaotic process of birth itself, and its association with - even dependence on - the problematic figures of midwives and gossips. The early modern midwife was a figure invested with patriarchal power not only because she controlled access to and information issuing from the birthing chamber, but also because of the folk belief that she was able to form the newborn's body and possibly even its gender. No longer charged with the responsibility of baptizing sickly-appearing newborns, she still bore responsibility for certifying a child's paternity, even if she had to threaten a labouring mother to get the information. ${ }^{36}$ This solemn responsibility was closely enough linked to the tattling realm of 'women's business', however, to maintain a simultaneous satiric identification with the figure of the tattling gossip, and with the general problem of female social disorder. ${ }^{37}$ For this reason, when the hag/gossips are harnessed to the chariots drawing the queens from the House of Fame to the masquing stage, the courtly audience is given a visual reminder that even the most ancient traditions surrounding female sexuality could be - and were - conscripted into the service of legitimate succession.

In spite of the urgent legal importance of the midwife's role, literary and popular representations of the gossip's gathering tended to depict it as merely an 'all-female playhouse,' a site of subversive tale-telling. ${ }^{38}$ To further complicate the metaphor, Epicoene, which Jonson probably began writing shortly after Queens, was written for the Children of the Queen's Revels, one of the last companies to be made up entirely of boy-actors. The disruptive female gossips were played by boys or perhaps older actors in 'dame' roles; such 
casting was entirely unremarkable. ${ }^{39}$ The title character, however, is revealed at the end of the play (in a rare case of the audience being surprised at the same moment as the characters on stage) to be a boy actor. In a metatheatrical sense, the whole production takes place in a space that was sexually analogous to 'an all-female playhouse'. And, while Epicoene does not present the textual problems that Queens does, its stage history presents analogous complications.

Epicoene features a group of masculinized women who 'call themselves the Collegiates ... live from their husbands and give entertainments to all the Wits and Braveries of the time ... with a most masculine or rather hermaphroditical authority' $(1.1 .71-5) .{ }^{40}$ Their sexual grotesquerie is underlined in their names; one woman is named Centaure, referring to the half-horse, half-male-human creature, and another is Mistress Otter, named for the amphibious mammal whose playful litheness was equated with sexual voraciousness as well as indeterminacy. They are really a group of gossips who have elevated themselves to a college, the purpose of which is to exchange tips on shopping and sexual adventures. According to Truewit, they have no real judgment, but that 'all their actions are governed by crude opinion, without reason or cause; they know not why they do anything, but as they are informed, believe, judge, praise, condemn, love, hate, and in emulation one of another do all these things alike' (4.6.58-62). In the course of his comedy, Jonson further denatures the gossips' gossip to the extent that it not only is divorced from things procreative, but also actually focuses on the avoidance of childbearing and family life. ${ }^{41}$ In other words, these gossips gather not to form a community around the creation of new life, but to deconstruct the normal forms of community related to family and economic consumerism. ${ }^{42}$ The Collegiates welcome a new 'recruit' in the person of Epicoene, and promise to share with her their tips on cosmetics, shopping, aphrodisiacs, abortifacents, and husband control.

The chatter of the gossips' gathering was male-defined in this period as a threat to paternal authority, whether implicit or explicit. ${ }^{43}$ A contemporary pamphlet offers a typical depiction of women gathered to drink and complain about their husbands' shortcomings, behavioral, sexual, and economic:

Sixe Gossips that of late together met,

Besprinckled finely, well with Claret wet:

Apt to discourse of all that ere they knew,

As tis the humor of the Gossip-crew,

Did find themselves greatly agrieved all, And each her Husband into question call. ${ }^{44}$ 
The Collegiates, like the hags of Queens, take the role of gossip one step further: not content with simply criticizing men, their respective projects parody the rituals of domestic life, producing noisy babble where there should be festive mirth surrounding a legitimate union. The appearance of Epicoene offers them a welcome opportunity to put on a 'wedding' that is in fact a charivari. ${ }^{45}$

The sensory experience of Epicoene parallels that of Queens. The sterile hags are associated repeatedly with noise: discordant music, chanting, gossip, emasculating shrewishness that both reflects and creates an image of female sexuality as unruly; similarly, the shrill gossips of Epicoene are the bane of their comic target, Morose, a recluse with a pathological hatred of noise whose bride has been offered to him solely on the basis of her supposed modesty and silence. Their union unites neither families nor hearts, but rather seeks to exclude Morose's nephew from his inheritance. The gossips rightly judge that Morose, whose reclusiveness and fear of noise represents his impotence, and whose openly stated purpose in marrying is to deprive his nephew, is not fit for marriage. They gleefully propose to teach Epicoene how to dominate her bridegroom, but they have themselves been manipulated into this activity by Truewit, who rightly judges that the noise of their festivities will madden the silence-loving Morose into agreeing to restore his inheritance in exchange for nullifying the marriage. When he claims impotence to get out of the marriage, the Collegiates volunteers to perform the traditional task of midwives and 'search' Morose, even though his legal advisor requested a 'jury of physicians' $(5.4 .54-6) .46$

Morose is an open misogynist, associating city women with noise and androgyny, with some justification. Ironically, Morose himself displays a hyperaggressive logorrhea, speaking for long paragraphs about his insistence on silence and engaging with Truewit in a vigorous duet of curses for the barber Cutbeard. It is only others' speech he finds intolerant, specifically because his imposition of silence is an expression of his desire for power over others: when he discovers that his 'silent' bride is actually a shrew, he cries, 'She is my regent already! I have married a Penthesilea, a Semiramis, sold my liberty to a distaff?' (3.4.51-2), and penultimately sums up his predicament: 'Marry a whore! And so much noise!' (5.4.139). His fear of talk is explicitly a fear of a challenge his authority. Mistress Otter is 'that Gorgon, that Medusa,' her domineering treatment of her husband as terrifying to Morose as the Dame's vindictive fury (3.7.20). However, where the Dame is silenced and harnessed to a cart, Mistress Otter and her husband 'shall be reconciled', possibly due to the erotic allure of seeing her husband spout Latin in a false beard to torment Morose (5.4.204). 
Morose's misogyny, however, does not represent the play's worldview. Although the Collegiates are (or claim to be) adulterers, abortionists, consumers, and slanderers, they are not really punished or humiliated at the end of the play, strongly hinting that both the wits and the boy who was formerly Epicoene will continue to enjoy their favours. ${ }^{47}$ ' $[\mathrm{H}]$ ere stands she that has vindicated your fames', notes Truewit, contrasting the woman-saving silence of Epicoene with the chatter of the 'common moths of these and all the ladies' honours', the 'insectae' Daw and La Foole, whose chatter is more effeminate than that of the Collegiates (5.4.228-9, 223-4). In the case of the play, the 'gossips' who gather to abuse their husbands are justified and the male chatterers who abuse women are exposed as slanderers. The men of the play, therefore, are the ones who suffer: Morose faces the loss of one-third of his income, and La Foole and Daw, the fops and presumed lovers of the Collegiates, are exposed as either liars or homosexuals (or both) for claiming to have had sex with Epicoene.

Lanier suggests that the play's ending deliberately frustrates the social and literary fantasy that Jonson shared with his classical models of a purely masculine discursive world; ${ }^{48}$ similarly, some feminist critics suggest that the staging of Queens invests the silent queens with the discursive energy of the hags while distancing them from the hags' destructive sexuality. ${ }^{49}$ Certainly the 'all-sounding brass' of the House of Fame - symbolizing the tendency of good deeds to echo down the ages - finds an ironic echo in Morose's complaint, 'they have rent my roof, walls, and all my windows asunder, with their brazen throats' (4.2.116-17). The House of Fame is an emblem of poetry and its power to immortalize; that it is occupied by queens is less important than that the poetry it represents is 'men-making' (362). Morose's house is its antithesis: a projection of its owner's pathological misogyny, which is destroyed upon being invaded by women. The House of Fame is a monument occupied by representations of silent women whose fame, at least, is eternized; Morose's house becomes, in Dauphine's summation, his tomb, which he is invited to 'go in and rest, and be as private as you will .. till you trouble me with your funeral'; damned not by female speech but by male wit (5.4.199-201). Tomb or monument, both structures are built upon the momentary silence that echoes in the cessation of noise. A 'sudden . . sound of loud music, as if many instruments had made one blast' silences the grotesque music of the hags in Queens (334-5), as the removal of Epicoene's peruke silences Morose's malicious loquacity. But silence is not the chief end of Jonson's preferred model of stoic reticence: 'A wise tongue should not be licentious, and wandring; but mov'd, and (as it were) govern'd with certaine 
raines from the heart, and bottome of the brest' (Discoveries, 330-2). The ideal is not the absence of sound, but the triumph of harmony over dissonance, represented in the two works by the courtly fanfare that ushers in the ladies of Queens, or the merry resolutions proposed by Truewit immediately following the summary paradox of Epicoene:

Clerimont. A boy.

Dauphine. Yes, Mistress Epicoene

In fact, Truewit's final commentary blends seamlessly into an epilogue of remarkable economy: 'Spectators, if you like this comedy, rise cheerfully, and now Morose is gone in, clap your hands. It may be that noise will cure him, at least please him' (5.4.235-7).

But while Morose may be cured by the productive sound of applause, the gossips are merely silenced, any 'mysteries' they may have 'discovered' to Epicoene subject to the discretion of the 'Silent Woman' (5.4.231). 'Madams, you are mute upon this new metamorphosis!' observes Truewit, and well they might be (5.4.227-8). The gossips have witnessed not a traditional lying-in but the emergence of a new pan-sexual creature, 'A boy ... Mistress Epicoene', the progeny of Dauphine alone. Like the hags of Queens, the Collegiates' traditional function has been travestied, in this case merrily, as the new boy Collegiate will soon become 'a good visitant' and sexual partner (5.4.232). The silencing of the gossip is therefore not itself misogynistic, as Jonson has shifted the definition of 'the gossip' from that of 'tattling woman' to that of 'tattling credulous fool', regardless of gender; Daw and La Foole, by acting as male attendants to the gossips, are the most heavily punished transgressors.

In silencing the gossip twice over, in both his preferred genres of drama, Jonson cannily reflects the impatience James was apparently suffering with his family - particularly the female members - in the years of 1608-9. Whether or not James's 'nourish-father' metaphor was an unconscious reflection of his own discomfort with female/maternal rule, he must certainly have been aware that it was losing its effectiveness on both the personal and political levels.

In addition to his marital conflicts with Anna, James was clashing with her and Henry over candidates for Princess Elizabeth's marriage; the sources of division were both religious and political. At the same time, his cousin Arbella Stuart was also agitating for permission to marry, a situation which must have put some additional pressure on James's desire to see his own line of succession secured. James' relationship with Arbella had been problematic for most of the cousins' lives, primarily because Arbella was seen by almost everyone as 
an alternative to James' monarchy, both before and after his accession. Following the death of her domineering grandmother, Bess of Hardwick, Arbella was becoming increasingly insistent that James allow her to marry, and her secret marriage in 1610, to William Seymour (against James's direct prohibition) brought Arbella, whether she intended it or not, even closer to the throne.

Although she had little luck with her cousin, Arbella did nearly succeed in destroying Epicoene. The play was banned shortly after its first performances because Arbella complained that she was being lampooned in the title character; her anger was directed at a single line in the play linking Epicoene with 'The Prince of Moldavia,' a real-life adventurer who had bilked James and other courtiers out of significant amounts of cash and with whom marriage negotiations with Arbella were rumoured. The ban may not have lasted long past Arbella's disgrace for marrying Seymour in 1610: there is indirect evidence that a 1612 quarto edition of the play was planned, and Jonson's 1616 folio edition includes the problematic Moldavia passage. While no direct evidence shows that the play was performed at court, no doubt Jonson expected it to be performed there when he wrote it.

The gossips of the antimasque as well as those of the city comedies were, of course, intended to offer satiric contrasts to normative examples of royal and courtly virtue; no direct association between the various gossips of 1609 and Anna, Arbella, or any other court lady was likely to have been intended by Jonson. An unacceptable level of misogyny may have been perceived, however; Arbella certainly assumed she was being lampooned as a figure of masculine sexual appetite, and Anna commissioned only two masques after Queens, Samuel Daniel's Tethys' Festival (1610), for Henry's investiture as Prince of Wales, and Jonson's Love Freed from Ignorance and Folly (1611), an inferior masque that was originally intended for the Christmas 1609-10 festivities, and in which Anna and her ladies merely danced without representing specific figures. ${ }^{50}$ Anna by no means abandoned courtly patronage or even masque participation after Queens; she merely shifted her 'cultural energies' to masques in locales outside London, participating in Whitehall masques either silently, from the audience, or behind the scenes. ${ }^{51}$

But even those critics who argue that Anna's active patronage of the masque continued past 1610 admit that, in the two years after 1609, Jonson focused his masquing energies on the heir, while still maintaining a careful attention to his monarch's perspective. Oberon (1610-11) represents a stunning celebration of the young prince's popularity and personal gifts, but also overtly presents 'the voluntary subordination of the heir' to James's image and 
interests. ${ }^{52}$ The grotesque gossips of the Queens antimasque are replaced by tipsy, cheerfully profane, hyper-masculine satyrs, whose chief, Silenus, owes direct allegiance to James (himself comfortable with his own reputation for drink, bawdry, and preference for the company of men). Had Henry survived, the hints of his artistic and personal ascendance in Oberon might have been made even more explicit in Jonson's masques; evidence that Jonson was abandoning James for Henry, however, is not conclusive. ${ }^{53}$ Jonson's allegiance to James, while certainly a complicated one in literary terms, would remain his primary one, at least until the ascendancy of the Duke of Buckingham ten years later.

Jonson's most successful dramatic strategy nearly always lay in deferring judgment to an idealized 'other' not immediately present in the world of the stage. ${ }^{54}$ Somewhere between the babble of the hags and silence of the court ladies atop the House of Fame, between the chatter of the gossips and Morose's sterile silence, lay true judgment, most likely to be found either with the observing monarch or the hypothetical possessor of the 'cunning palate' needed to understand the satire of Epicoene without taking offense (Prologue, 10). Near the end of Queens, Jonson comments in his annotations, 'let the looks and noses of judges hover thick, so they bring the brains, or if they do not, I care not' (449n, p. 547). However, the attention-grabbing noise of the gossips, who, in the guise of witches, were sure to rivet James's attention, implies that Jonson was taking no chances in manipulating his sovereign's judgment in favor of the poet as the source of true fame.

The vivid imagery of the Queens antimasque may reflect Jonson's attempt to appeal to the rhetorical preferences of a monarch whom he may have perceived as sharing his personal disappointments about marriage and childrearing. The binary pair of furious Dame and serene Bel-Anna ultimately have little to do with mothers of any kind; they are at best dramatizations of the kind of poetic gender-models Jonson chose from, depending on his epigrammatic needs at any one time. The masque's internal tensions are so deeply rooted in the politics of occasion and the language of gesture as to present an abstraction of, rather than a specific commentary on, the various monarchial agendas at play. If the aesthetic of the masque is, as Tom Bishop has argued, 'The ritual of the future perfect,' or a celebration of timelessness and deferral, this would account for the indeterminacy of the actual female subject of the masque. ${ }^{55}$ The satire of Epicoene, operating as it does in the (relatively) more permissive context of the children's stage, can afford to be more explicit about associating effeminate pretension and rhetorical folly - whether practiced by men or women - with the dissolution of the nuclear family. The creation of 
the character of Epicoene is not just a possible precursor to a new kind of stage comedy, but potentially a figure through which Jonson can express his ambivalence about depicting, in John Donne's ironic construction, 'mind in women; at their best/Sweetness and wit'. ${ }^{56}$ The witty boy-woman represents an impossible ideal of rhetorical self-possession, eloquent in silence. Neither a gossip (although she pretends to be one) nor a silent queen (although she masquerades as one) nor a witty male (although she promises to become one), she becomes a living emblem that belongs in the same family as James's 'nourish-father' metaphor, but also looks forward to the Jacobean court's domination by beautiful young men like Prince Henry and Robert Carr. Jonson was too careful an author to alienate his female patrons, but by developing a model of wit that seems always to be potential rather than actual, defined in opposition to the immediate, quotidian concerns of the gossip's gathering, he narrows the opportunities for both men and women to live up to a standard of eloquence that purports to transcend gender.

\section{Notes}

1 Journal of the House of Commons I: 193, qtd. in Alan Stewart, The Cradle King: A Life of James I (London, 2003), 216. In fact, Stewart notes, 'Bruised by the failure of the Union, the attacks of the Puritans, and the increasingly uncooperative Commons, James felt his popularity to be at an all-time low' in 1608 .

2 C.H. McIlwain (ed), Political Works of James I (Cambridge, Mass., 1918), 272.

3 See Douglas M. Lanier, 'Brainchildren: Self-Representation and Patriarchy in Ben Jonson's Early Works', Renaissance Papers (1986), 53-68; David Riggs' psychoanalytical biography, Ben Jonson: A Life (Cambridge, Mass., 1989); Jonathon Goldberg, James I and the Politics of Literature (Stanford, 1989), esp.85-112; Kristen McDermott, “He may be our father, perhaps”: Paternity, Puppets, Boys and Bartholomew Fair', in Robert N. Watson (ed), Critical Essays on Ben Jonson (New York, 1997), 60-81; and Mark Bland, 'Ben Jonson and the Legacies of the Past', Huntington Library Quarterly 67.3 (2004), 371-400.

4 'Marginal Jonson', in David Bevington and Peter Holbrook (eds), The Politics of the Stuart Court Masque (Cambridge, 1998), 144-75, esp. 167-8; see also Kate D. Levin, 'Unmasking Epicoene: Jonson's Dramaturgy for the Commercial Theater and Court', in James Hirsh (ed), New Perspectives on Ben Jonson (Madison, 1997), 128-53, for a specific comparison of Jonson's craft in the two works. In 'Masculine Silence: Epicoene and Jonsonian Stylistics', College 
Literature 21.2 (1994): 1-18, Douglas Lanier discusses Jonson's attempts to define an explicitly masculine gendered style in Queens and Epicoene, but does not examine the depiction of the hags specifically.

5 Riggs, Ben Jonson: A Life, 146.

6 Underwoods, Epigram XLIX, in C.H. Herford, Percy and Evelyn Simpson (eds), Ben Jonson, 11 vols. (Oxford, 1925-52), 7:222.

7 Riggs, 152-3.

8 See, for example, Kathryn Schwartz, 'Amazon reflections in the Jacobean Queen's masque', SEL 35.2 (1995), 293-319, who argues that the figure of the Amazon challenges or complicates the totalizing discourse of the masque, offering an alternative to or a criticism of James's patriarchal discourse. Such readings are designed to challenge Orgel's influential assertions that the competing agendas evident in the inconsistencies of Queens are in fact resolved in the interest of the monarch; see 'Jonson and the Amazons', in Elizabeth Harvey and Katharine Maus (eds), Soliciting Interpretation: Literary Theory and 17 th Century English Poetry (Chicago, 1990), 119-39.

9 Jonas Barish, for example, notes, 'Instead of release, for which the nature of the plot prepares us, the end brings constriction', in Ben Jonson and the Language of Prose Comedy (Cambridge, Mass., 1960), 185; Lanier makes the same observation in a more recent, gender-related context when he notes that Jonson's 'fantasy of masculine discursive control' is ironized to the point of failure ('Masculine Silence', 14).

$10 O E D$ (n. 3). Adrian Wilson has suggested that the figure of the gossip is closely tied to the overall 'ceremony of childbirth,' a site of temporary female challenge to male authority; see 'The Ceremony of Childbirth and its Interpretation,' Valerie Fildes (ed), Women as Mothers in Pre-Industrial England: Essays in Memory of Dorothy McLaren (London, 1990), 68-107, 97. More recent scholars, however, have noted that feminist historians have overstated the close 'sisterhood' implied by the community of gossips and birthing women, and that such relationships were ambivalent at best. See Deborah Willis, Malevolent Nurture: Witch-Hunting and Maternal Power in Early Modern England (Ithaca, NY, 1995); Linda A. Pollock, who notes in 'Childbearing in Early Modern England', Social History 22.3 (1997), 286-306, that the lying-in room in early modern Europe was at best an ambiguous site of female 'community culture' (288); and Gail McMurray Gibson, 'Scene and Obscene: Seeing and Performing Late Medieval Childbirth', Journal of Medieval and Early Modern Studies 29 (1999), 7-24. 
11 In Chaucer, Lady Fame dispenses her gifts capriciously and is compared to the many-eyed Beast of the Apocalypse; see The House of Fame, 1385, Larry D. Benson, et al (eds), The Riverside Chaucer (Boston, 1987), 364. In Chaucer's source, Virgil's Aeneid, Fame is 'a monstrous phantom, horrible and vast', her actions more reminiscent of the seditious talk of the hags than anything else:

Millions of opening mouths to Fame belong,

And ev'ry mouth is furnish'd with a tongue,

And round with list'ning ears the flying plague is hung. ...

Talk is her business, and her chief delight

To tell of prodigies and cause affright

in John Dryden's translation, Frederick Keener (ed) (Penguin, 1997).

12 See for the former interpretation Suzanne Gossett, "Man-maid, begone": Women in Masques', ELR 18.1 (1988), 100-1; Margaret Maurer, 'Reading Ben Jonson's Queens', in Sheila Fisher and Janet E. Halley (eds), Seeking the Woman in Late Medieval and Early Renaissance Writings (Knoxville, 1989), 237; and Orgel, 'Jonson and the Amazons'. Such readings have been challenged more recently by critics like Leeds Barroll, 'Inventing the Stuart Court Masque,' in Bevington and Holbrook, The Politics of the Stuart Court Masque, 121-43; and Clare McManus, Women on the Renaissance Stage: Anna of Denmark and Female Masquing in the Stuart Court (Manchester, 2002), both of whom stress Anna's careful use of the masque form for her own political and ideological purposes, and Jonson's cooperation in that project.

13 Steve Brown, 'The Boyhood of Shakespeare's Heroines', SEL 30.2 (1990), 243-63, whose reading attempts to challenge Jean Howard's assertion, in 'Crossdressing, The Theatre, and Gender Struggle in Early Modern England', Shakespeare Quarterly 39.4 (1988), 418-40, that 'male crossdressing becomes a way to appropriate and then erase the troubling figure of wife' (430). Helen Ostovich, in the introduction to her edition of the play in Ben Jonson: Four Comedies (London, 1997), suggests that Epicoene supplies a 'strong sympathetic female response to an intolerable marital situation', thereby 'complicat [ing] the [play's] view of sexual relations' (29).

14 See Helen Ostovich, 'Ben Jonson and the Dynamics of Misogyny: A Cultural Collaboration', The Elizabethan Theatre XV (2002): 107; and Rebecca Merrens, "'Ignoring the Men”: Female Speech and Male Anxiety in Cavendish's The Female Academy and Jonson's Epicoene' In-Between: Essays \& Studies in Literary Criticism 9.1\&2 (2000), 243-60.

15 Lanier argues that Epicoene's status as an 'Amazon' ironizes the term, 'transposing the masculinized woman of The Masque of Queenes from the feminine 
discursive realm, where he/she embodies female power, to the masculine discursive realm, where he/she serves the ends of Dauphine' ('Masculine Silence', 13-14).

16 Brown asserts that when Morose seeks the impossible — a silent bride - he actually imitates the male wits (and recapitulates his source-model in $I l$ Marescalco) with his desire for an 'ingle at home' (258). This is a useful way to think about the complexities of gender-identity Jonson creates when he inverts Shakespeare's 'boy-plays-girl-playing-boy' paradigm into 'boy-plays-boy-playing-girl'; however, such an argument ignores the fact that Morose's explicit reason for marrying is to get an heir. Epicoene, although secretly a boy, certainly represents a model of purely female loquacity throughout the play and is as silent as the Collegiates at the play's end.

17 Martin Butler, 'Courtly Negotiations', in Bevington and Holbrook, The Politics of the Stuart Court Masque, 28.

18 A notable exception is Lynn Sermin Meskill's 'Exorcizing the Gorgon of Terror: Jonson's Masque of Queenes', ELH 72 (2005), 181-207: she suggests that the hags and the Gorgon-like Dame represent the 'terror' of maternal power, with its potential to both create and 'cut off the male life force, disquieting both the patriarchal poet and the patriarchal state.

19 Stephen Orgel (ed), The Complete Masques (New Haven, 1969), 122-41. All references to the text of Queens are from this edition and are subsequently cited parenthetically.

20 Lawrence Normand explicates the relationship between James's witchcrafttract, Daemonologie, his paternal metaphor, and Queens in 'Witches, King James, and The Masque of Queens', in Claude J. Summers and Ted-Larry Pebworth (eds), Representing Women in Renaissance England (Columbia, MO, 1997), 107-20.

21 Arthur Little examines the tendency of the Jacobean stage to evoke while not explicitly depicting taboo or obscene tableaux in “'An Essence that's Not Seen”: The Primal Scene of Racism in Othello', Shakespeare Quarterly 44.3 (1993), 304-24.

22 The Illusion of Power (Berkeley, 1991), 37-8. Marion Wynne-Davies also asserts the close connection between folk ritual and the masque in 'The Queen's Masque: Renaissance Women and the Seventeenth-Century Court Masque', in S.P. Cerasano, Marion Wynne-Davies (eds), Gloriana's Face: Women, Public and Private, in the English Renaissance (Detroit, 1992), 89.

23 'The Gingerbread Host: Tradition and Novelty in the Jacobean Masque', in Bevington and Holbrook (eds), The Politics of the Stuart Court Masque, 94. 
24 Willis, Malevolent Nurture, has attempted to sort out the 'village-level' folk practices from the 'official' portrait of the early modern English witch, and notes the effort to subsume the complex social and psychological patterns of folk belief into a controlled, authoritarian discourse. She argues that, with the passage of various anti-witchcraft laws 'in 1563, magistrates and other members of the learned elites intervened in and to some extent transformed a pre-existing body of popular beliefs about witches and a set of informal witch-hunting practices; they did not create them,' 29.

25 See, for example, Wynne-Davies and Schwartz. Such readings generally argue that the figure of the Amazon challenges or complicates the totalizing discourse of the masque, offering an alternative to or a criticism of James's patriarchal discourse. Stuart Clark's exhaustive sociological study of witchcraft and early modern culture notes conventionally that the witches of Queens represent an 'antithetical conception of court life' and Neoplatonic order, providing a foil for the power of the monarch (Thinking with Demons: The Idea of Witchcraft in Early Modern Europe [Oxford, 1997], 92; Willis' analysis of the pervasive maternal imagery that dominates early modern witch-lore and witch-hunting does not mention The Masque of Queens at all.

26 'Jonson and the Amazons', 125-6, 16n. Goldberg argues similarly that Perseus 'acts as a kind of male mother', 88.

27 See Gossett's contention that Jonson deliberately suppressed details and imagery that emphasized the martial activities of the queens from the performed masque that he did provide in the marginalia (100-1). Maurer suggests, 'the ladies of Queens ... are lurking in the shadows of Jonson's text, daring us to imagine them and the threat they pose to the masque's meaning,' forcing feminist critics to read against Jonson's purpose, which is to silence and denigrate the court women (237).

28 Current social history has carefully examined the rituals of the birthing-room, banishing at the same time the fantasy that they created a privileged female space free of patriarchal oppression. In fact, as Laura Gowing notes, 'The divisions between women that helped enforce gender order outside the birthroom were likely to be reinforced inside it'; see Common Bodies: Women, Touch and Power in Seventeenth-Century England (New Haven, 2003), 150. In this context, the display of the Dame's attempts to effect a grotesque birth parallels the actual situation of noble birthings, which were even more carefully monitored than those of the commons. And, while privacy in childbirth was a privilege of the upper classes, that privacy was at best nominal, as the attendants usually acted on behalf of elite concerns about legitimacy. 
29 The Chamberlain Letters, qtd in David Bergeron, Royal Family, Royal Lovers: King James of England and Scotland (Columbia, MO, 1991), 115.

30 Jonson himself was not above sharing well-lubricated gossip with male friends, as the Conversations recorded by William Drummond attest. His observations that 'Queen Elizabeth never saw her self after she became old in a true Glass', that her courtiers gave her false dice so that she would always win, and that 'she had a Membrana on her which made her uncapable of man, though for her delight she tried many', usher in a number of sneering remarks about 'great ones' (Herford and Simpson, 1:141-2, 11. 336-44).

31 See Riggs, 155.

32 James I, Daemonologie (London, 1603), 66-7, Early English Books Online, $<$ http://0-eebo.chadwyck.com.catalog.lib.cmich.edu/>, accessed 17 October 2005.

33 Willis, 37.

34 Bergeron, 86. Willis connects witch fears to the common early modern trauma of child death, in Malevolent Nurture, 60-1.

35 Edward Cokes, A Detection of the Court and State of England during the Reigns of King James, 4th ed, 3 vols (1694, repr 1729), 1:71, 43n, cited in Bergeron, 92.

36 Gowing, 159-61. However, the once-popular assumption that midwives were commonly demonized as witches has been thoroughly debunked; rather, they were more likely to be acting on behalf of patriarchal authority by certifying legitimacy. See, for example, David Harley, 'Historians as Demonologists: The Myth of the Midwife-Witch', Social History of Medicine 3 (1990), 1-26; and Sara Mendelson and Patricia Crawford, Women in Early Modern England (Oxford, 1998), 148-9.

37 Mendelson and Crawford, 215-17.

38 Caroline Bicks, Midwiving Subjects in Shakespeare's England (Ashgate, 2003), 17. See also Gail Kern Paster, The Body Embarrassed: Drama and the Disciplines of Shame in Early Modern England (Ithaca, NY, 1993), esp. 55-63.

39 Even though the boy actors were mostly between the ages of 13 and 20 by this time, theatrical and erotic convention gendered them as feminine. See Phyllis Rackin, 'Androgyny, Mimesis, and the Marriage of the Boy Heroine on the English Renaissance Stage', PMLA 102(1987), 29-41; Jean E. Howard, 'Crossdressing, The Theatre, and Gender Struggle in Early Modern England'; Stephen Orgel, "Nobody's Perfect, or Why did the English Stage Take Boys for Women?', The South Atlantic Quarterly 88 (1989), 7-29; Brown, “The Boyhood of Shakespeare's Heroines'; Lisa Jardine, 'Boy Actors, Female Roles, 
and Elizabethan Eroticism', in David Scott Kastan and Peter Stallybrass (eds), Staging the Renaissance: Reinterpretations of Elizabethan and Jacobean Drama (New York,1991), 57-67; Peter Stallybrass, 'Transvestism and the "Body Beneath": Speculating on the Boy Actor', Susan Zimmerman (ed), Erotic Politics: Desire on the Renaissance Stage (New York, 1992), 64-83; Richmond Barbour, "When I acted young Antinous": Boy Actors and the Erotics of Jonsonian Theater', PMLA 110 (1995), 1006-22; and David Kathman, 'How Old Were Shakespeare's Boy Actors?', Shakespeare Survey 58 (2005), 220-46.

40 Ben Jonson, Epicoene, R.V. Holdsworth (ed) (Manchester, 1979, repr 1990); all quotations are from this edition.

41 On Epicoene's assertion that 'the Ladies Collegiate imitate male privilege by wielding the power of sexual choice, a choice that includes neither monogamy nor procreation on demand', see Ostovich's introduction in Ben Jonson: Four Comedies (London, 1997), 28. She also suggests that Jonson returned in The Magnetic Lady and The Sad Shepherd to metaphors that depicted women bent on usurping social and sexual power as monstrous mothers; see 'The Appropriation of Pleasure in The Magnetic Lady,' in Susan Frye and Karen Robertson (eds), Maids and Mistresses, Cousins and Queens: Women's Alliances in Early Modern England (Oxford, 1999), 134-55.

42 For discussion of the play's gendered depictions of consumerism, see Karen Newman, 'City Talk: Femininity and Commodification in Jonson's Epicoene', in Fashioning Femininity in the English Renaissance (Chicago, 1991); Marjorie Swann, 'Refashioning Society in Ben Jonson's Epicoene”, SEL 38.2 (1998), 297-315; and W. David Kay, 'Epicoene, Lady Compton, and the Gendering of Jonsonian Satire on Extravagance', Ben Jonson Journal 6 (1999), $1-33$.

43 Mendelson and Crawford, 66-7.

44 S. Rowlands, A Crew of kind Gossips, all met to be Merrie (London, 1613), A1-2.

45 See Bruce Thomas Boehrer, 'Epicoene, Charivari, Skimmington,' English Studies 75 (1994), 17-33.

46 This line calls up associations with the infamous 1613 court case that allowed Frances Howard to order an examination proving the alleged impotence of her husband, the Earl of Essex, in order to marry James's favorite.

47 See Swann, 302.

48 Lanier, 'Masculine Silence', 14.

49 See Schwartz, 294; Wynne-Davies, 85; and Barbara Lewalski's contention that the sight of the hags pulling the Amazons' wagons confers their subversive power 
on the silent queens, in 'Anne of Denmark and the Subversions of Masquing', Criticism 35 (1993), 341-55. McManus, however, suggests that for the chariotbound witches and the House-of-Fame-bound queens, 'the experience of confinement was shared' (119).

50 Leeds Barroll argues that Henry and Anna's 1611 masques, Oberon and Love Freed, were joint productions and should be considered of equal status; see Anna of Denmark, Queen of England: A Cultural Biography (Philadelphia, 2001), 128-9.

51 McManus, 164-5.

52 Jean E. Graham, 'The Performing Heir in Jonson's Jacobean Masques', SEL 41.2 (2001), 397.

53 Butler suggests that 'Oberon can be seen as participating in transactions which, while not subverting the King, nonetheless involved a significant challenge to him', but admits that perceiving 'a royal discourse in crisis' in the text of Oberon is somewhat conjectural (31).

54 See, for example, Michael Shapiro, 'Audience vs. Dramatist in Jonson's Epicoene and Other Plays of the Children's Troupes', ELR 3 (1973), 400-17; Stanley E. Fish, 'Authors-Readers: Jonson's Community of the Same', Representations 7 (1984), 26-58; and Robert N. Watson, Ben Jonson's Parodic Strategy: Literary Imperialism in the Comedies (Cambridge, Mass., 1987).

55 'The Gingerbread Host', 94.

56 'Love's Alchemy', 23-4, John Donne, John Carey (ed) (Oxford, 1990). The difficulties presented by Donne's punctuation of this line are, of course, both well-documented and apt. 